ppi $201502 Z U 4645$

Esta publicación científica en formato digital es continuidad de la revista impresa ISSN-Versión Impresa 0798-1406 / ISSN-Versión on line 2542-3185Depósito legal pp $197402 Z$ U34

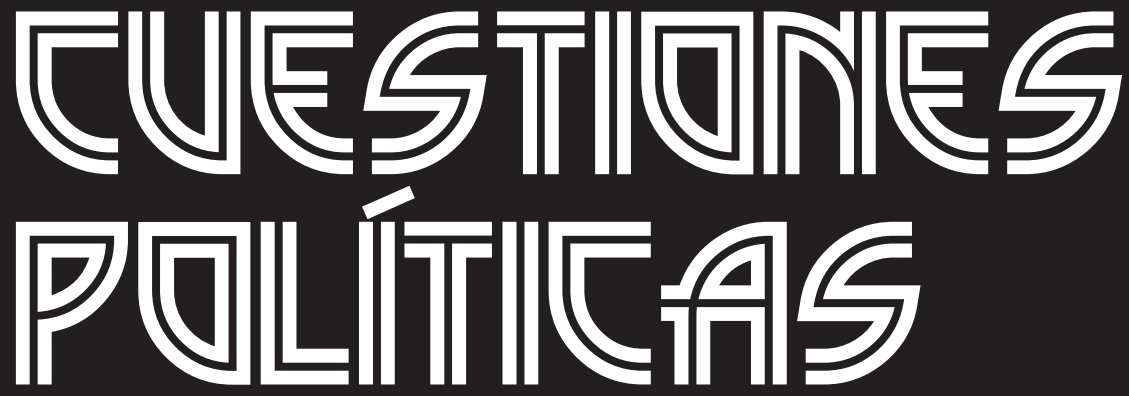

Instituto de Estudios Políticos y Derecho Público "Dr. Humberto J. La Roche" de la Facultad de Ciencias Jurídicas y Políticas de la Universidad del Zulia Maracaibo, Venezuela
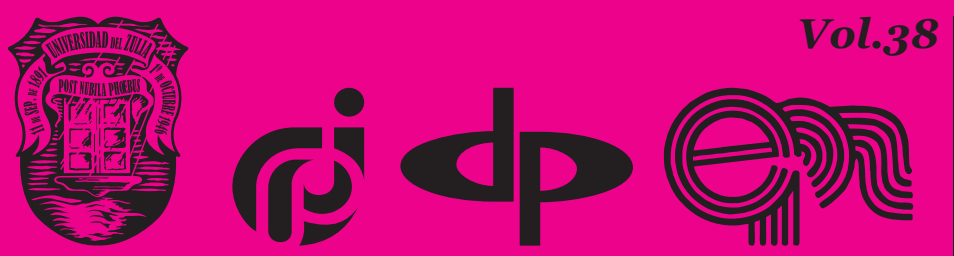

$N^{\circ}$ Especial 1era Parte 2020 


\title{
Christian interpretation of anthropological guidelines for lawmaking
}

\author{
DOI: https://doi.org/10.46398/cuestpol.38e.35
}

\begin{abstract}
Nesprava Mykola*
Rizak Mykhailo **

Volkov Vladlen ***

Voluiko Oksana ****

Skrypa Yevhenii *****
\end{abstract}

\section{Abstract}

The objective of the article is to reveal the main foundations of human creation enshrined in Christian doctrine, which serve as axiological guidelines for the elaboration of laws, providing a humanistic content of the law. The research methodology is based on dialectical, formal-dogmatic, sociological, comparative-legal and documentary methods. The results of the study demonstrate that theocentrism and anthropocentrism are not opposed to each other in Christianity, but rather are combined into an integrated theological and anthropological picture of a man. Considering this prism of legal consciousness as a reflection of the supreme law of God, the authors refute the secular-positivist view of "homo juridicus" as a soulless subject of law and emphasize the role of the Gospel commandments as a guide. for the elaboration of laws. It is concluded that the Christian vision of the synergistic interaction of the human being and the legislator through the unity of three incarnations: "homo spiritus" - "homo sapiens" - "homo juridicus" indicates the values, which are designed to ensure humanization of the law through the humanization of social relations in general.

Keywords: image of the human person; Christian doctrine; legal theology; Christian spirituality; human creation; law.

* Doctor of Philosophy, Associate Professor, Professor of the Department of International Relations and Tourism of Dnipropetrovsk State University of Internal Affairs. ORCID ID: https://orcid.org/ooooooo3-0415-1837. Email: post@naiau.kiev.ua

** Doctor of Law, Leading Researcher of the Scientific Institute of Public Law. ORCID ID: https://orcid. org/oooo-0002-9564-791X. Email: siplasl2019@gmail.com

*** Candidate of Technical Sciences, Senior Research Fellow of the Scientific Institute of Public Law. ORCID ID: https://orcid.org/oooo-ooo1-8419-9878. Email: sipl1@ukr.net

**** PhD in Law, Lecturer at the Department of Legal Psychology of the National Academy of Internal Affairs. ORCID ID: https://orcid.org/oooo-0001-5408-4332. Email: k015@naiau.kiev.ua

*****Doctor of Law, Principal Researcher of the Research Laboratory for Preventive Activities and Prevention of Corruption of the Educational and Scientific Institute №3 of the National Academy of Internal Affairs. ORCID ID: https://orcid.org/oooo-0002-9761-2307. Email: nnigb@naiau.kiev.ua 


\section{2 \\ Nesprava Mykola, Rizak Mykhailo, Volkov Vladlen, Voluiko Oksana y Skrypa Yevhenii \\ Christian interpretation of anthropological guidelines for lawmaking \\ Interpretación cristiana de las pautas antropológicas para la elaboración de leyes}

\section{Resumen}

El objetivo del artículo es develar los principales fundamentos de la creación humana consagrados en la doctrina cristiana, que sirven como directrices axiológicas para la elaboración de leyes, proporcionando un contenido humanista de la ley. La metodología de investigación se basa en métodos dialécticos, formal-dogmáticos, sociológicos, comparado-legales y documentales. Los resultados del estudio demuestran que el teocentrismo y el antropocentrismo no se oponen entre sí en el cristianismo, sino que se combinan en una imagen teológica y antropológica integrada de un hombre. Considerando este prisma de la conciencia jurídica como un reflejo de la ley suprema de Dios, los autores refutan la visión secular-positivista sobre el «homo juridicus» como un sujeto de derecho desalmado y hacen hincapié en el papel de los mandamientos del Evangelio como guía para la elaboración de leyes. Se concluye que la visión cristiana de la interacción sinérgica del ser humano y el legislador a través de la unidad de tres encarnaciones: "homo spiritus" - "homo sapiens" - "homo juridicus" indica los valores, que están diseñados para asegurar la humanización del derecho a través de la humanización de las relaciones sociales en general.

Palabras clave: imagen de la persona humana; doctrina cristiana; teología jurídica; espiritualidad cristiana; creación humana; ley.

\section{Introduction}

The appeal to human dimension of law is conditioned by the need to bridge the gap between normative and value content of law, which is evident in the EU countries, as well as manifests itself in the form of a series of political and legal crises in Ukraine. We can agree with the opinion of Ogneviuk (2018) that anthropological approaches to the study of legal phenomena allow to give law a value humanistic orientation, because the connection with anthropological teaching in jurisprudence is transformed into a relationship between the implementation of legal certainty and human rights. But the path to understanding the axiological guidelines of law (both lawmaking and law enforcement), which are established in a particular socio-cultural space, lies through the understanding of the essential attributes of a man.

The pragmatics of positivist legal methodology, which represents an individual as a separate subject of law in lawmaking and thus cuts 
off his (her) anthropological dimension, has caused a crisis of law as a means of resolving social conflicts. And ignoring the values defined by the Christian tradition has led to the paradoxical fact of legal protection of anthropologically incapable and even harmful to human nature phenomena (legalization of euthanasia, legal institutionalization of same-sex families, adoption and surrogacy in the interests of the latter), which contributes to the moral degradation of society. Overcoming socio and cultural and political and legal crisis must begin with a re-thinking of the teleological orientation of law-making, which has been artificially deprived of its deep spiritual content. Therefore, the study of Christian anthropological views as factors in the humanistic value orientation of the law-making process is an urgent task of modern philosophy of law.

The study of Christian anthropological heritage reveals new sides of the image of a man of the postmodern era. Its understanding proves that theology and anthropology are really interconnected, which expands the horizons of modern philosophical thought, offers humanity a way to solve urgent epistemological and anthropological problems and, last but not least, helps a person to understand himself (herself), the world and the God.

\section{Materials and methods}

The system of methods of scientific knowledge is chosen based on the purpose and objectives of the research. Among them are general scientific methods, methods of political science, sociology, philosophy, jurisprudence, as well as special methodological principles for studying the religious principles of development of law.

Dialectical method contributed to the study of the problem under consideration in the unity of its social content and legal form and the implementation of a systematic analysis of forms of interaction between religion and law.

With the help of historical and legal method the peculiarities of development of law under the influence of gospel commandments is revealed.

The normative basis for the religious origin of law is defined and characterized due to the formal and legal method.

Socio-prognostic method allowed to identify the features of the influence of Christianity on the formation and development of law.

Logical method makes it possible to identify and clarify the general mechanism of functioning of religion and law, as well as to reveal the 
Christian vision of synergetic interaction of human-creating and lawmaking through the unity of three incarnations - "homo spiritus" - "homo sapiens" - "homo juridicus".

In the course of the research the works of Elliot (2018), Foucault (2003), Kant (1995), Levinas (1997), Marchenko (2005), Nietzsche (2015), Ogneviuk (2018), Pavlov (2016), Predko (2019) and others were used, which proved that the study of Christian anthropological heritage reveals different parts of the image of a man of the postmodern era. The comprehension of this heritage proves that theology and anthropology are really interconnected, which expands the horizons of modern philosophical thought, offers humanity a way to solve urgent epistemological and anthropological problems and, last but not least, helps a person to understand himself (herself), the world and God.

At the sametime, itshould beemphasized that the study of anthropological aspects of Christianity and the study of humanistic principles of law making do not intersect in modern science, so the attempt to combine these two areas of philosophical thought is a novelty of our work.

\section{Results}

The presented religious-synergetic concept is based on the type of human understanding, which, on the one hand, is a traditional way of describing the attributive essence of a man in Christian anthropology and determines the Christian interpretation of human creativity, and on the other hand - uses the resources of modern postmodern thought, which acknowledges the crisis of classical rationalist-secularist anthropological ideas. The methodological resource of religious-synergetic theory is also used by us as an alternative to positivism in determining the role of the values of Christianity in lawmaking. This approach reveals the Christian vision of synergetic interaction of human-creating and lawmaking through the unity of three incarnations - "homo spiritus" - "homo sapiens" - "homo juridicus".

\section{Discussion}

The dominant philosophical and legal paradigm in Europe grew on the ideas of the Enlightenment, which considered the person through the prism of rationalism. This view, which is based on the belief in the omnipotence of the human mind, nowadays has become strongly opposed to the religious 
worldview (CC by European Values 2016). Its proponents state that the person by nature is a product of biological evolution, a species of homo sapiens (intelligent person). The secular concept assumes that the primary source of law is human mind; people themselves establish the laws of coexistence, because there is nothing else in the world except the natural space and the subjects of human rights.

However, a person as such is really absent in the system of secular rationality, because only the subject is present in it. A man and his Ego are placed in the center of the secular system of values formed on this basis. Thus, the goal of human creativity is the growth of this Ego, its selftranscendence up to the state of the superman through the improvement of mind and concentration of willpower. But concentrated individualism of secular rationalism also presupposes its reverse side - egocentrism, immorality, exploitative attitude to the world around. However, the supporters of the secular-rationalist paradigm do not notice that social system based on the absolute personal freedom of expression, which was promoted as the ideal of democracy, sooner or later becomes a zone of value-based conflicts between different social actors. That's why the critics of rationalist ideas about a man point out that the secularism has led to alienation, disappointment, lawlessness, etc., that is they argue that moral crisis is the greatest danger in the modern world. Under these conditions, philosophical and legal concepts opposing to rationalist-secularist positivism stress above all on the rethinking of anthropological principles of lawmaking.

The analysis of socio-cultural discourse shows that the classical model of a rational man, which is based exclusively on the Cartesian principle "cogito ergo sum", has failed. Modern religious philosophers argue that the following atheistic slogans such as "man is the king of nature" paradoxically lead to the dehumanization of the subject. They point out that the image of a man as homo sapiens created by classical rationalism has eventually became "a soulless computer". Following the logic of Friedrich Nietzsche (2015: 125), who predicted the inevitable "death of God" in a society of rational modernism, famous French philosopher Michel Foucault warns of the subsequent "scattering of man" (Foucault 2003: 114). And such scattering inevitably leads to the erosion of the value framework for law.

Thus, there was a need to turn to another anthropological paradigm in the philosophy of lawmaking. Defining its vector, we can agree with the conclusion of Ukrainian researcher Lyudmila Mykulanynets (2019: 49 50): "The anthropological crisis of the turn of the $20^{\text {th }}-21^{\text {th }}$ manifested itself through the conflict of humanism and anti-humanism. This is the evidence of the basic ideological opposites of human existence: man - God, reason faith, rationalism - irrationalism, tradition -innovation, etc. The problems raised in the 2nd half of the 2oth century ("death of God", "death of man", 
"end of history" can be solved through the reversion of a individual to the traditional religious truths of the Middle Ages: eternity of God, immortality of soul, infinity of history.

It should be emphasized that essential difference between Christian anthropology and atheistic understanding of a man lies in the belief in the soul. Thus, Christian anthropology has long been focused on the guiding principle of "credo ergo sum". According to this paradigm, the mind is used as an instrument of knowledge of the external world and oneself in it, while the immortal soul is the "gate" between God and a man. The existential difference between "reasonable self-production" as the desire to bring oneself in line with the system of spiritual values (Novik, 1999) advocated by Christian philosophy from the production of "mass man" is rooted in key biblical concepts common to Christian anthropology. It should be emphasized that the Christian tradition, like any other religious tradition, has certain basic anthropological ideas, i.e. the image of a man. The model of a human being in religious anthropology is based on the idea that human existence as personal existence is not reduced to human nature as a biological species. Christianity, unlike other religions, defends the image of a man, which in essence can be understood through its synergy. God-Father, God-Son and the Holy Spirit, who created a man, form into a cohesive unit only in Christian doctrine. Only Christianity reveals the image of a man as a synergistic unity of spiritual and material principles embodied in Christ. So, Christianity is the only doctrine according to which not only man ascends to God in the process of deification, but also God is embodied in man, that is, humanized.

The value core of the individual is presented primarily as homo spiritus (spiritual man) in the Christian interpretation. The essence of homo spiritus was most deeply revealed by prominent Ukrainian thinkers Hryhoriy Skovoroda and Pamfil Yurkevych, whose philosophy of the heart is based on the principles of Christian anthropology. While revealing the content of this concept, Ukrainian scientist Oleksiy Marchenko (2005: 167) notes: "The idea of God is manifested in the national religious and philosophical tradition not as a product of human thought, but as a living consciousness of the true unconditional being experienced in faith, the real image of which is the human, a living consciousness of godliness as the true purpose of human life. Hence the understanding of the search for God as a significant form of human self-determination and self-realization, the actualization of new spiritual and moral dimensions of their existence arises. Spirituality is a way of self-construction, an access to the highest value instances of one's own constitution, manifestation of the ontologically inherent desire for freedom, in which human involvement in the ultimate spiritual reality is directly manifested. 
Thus, Christianity, revealing a new revelation of a man, formed an anthropology that is not based on a strictly logical, inductive approach. Christian anthropology does not aim to simply structure the existing ideas about a man; it rather serves as a guide on the path of human creativity, the goal of which Christian thinkers see in the spiritual growth, purification and salvation of a man. At the same time, the essence of human creativity, according to Christian doctrine, is expressed primarily in the ability to selfless, divine love. At the same time, Christian anthropology does not idealize a man at all, because it also points to the reality of sin and guilt in human life. However, Christian understanding of a man remains optimistic because he is granted Salvation. The Christian faith in the Resurrection and dignity of every person acquired through the Savior is the basis of the modern concept of human rights.

It is the Christian understanding of the attributive essence of a man that determined the humanistic orientation of European law. The Commandment of Christ "Whatever you want people to do for you, you do it for them!", which He proclaimed in the Sermon on the Mount, is, in fact, the forerunner of the famous categorical imperative of Immanuel Kant (1995: 224) "Act so that the maxim of your behavior could be at the same time a principle of general law". These guidelines, which underlie the principle of justice, demonstrate the classic pattern of conformity between the "image of a man" and the "image of law". At the same time, essentially synergetic Christian anthropological interpretation of the goals of lawmaking strongly opposes secular individualism, because if the goal of social institutions, including law, is a man (according to Christian thinkers), then the goal of the individual is public good. The value orientation of the Christian anthropological concept is clearly characterized in the work of Ukrainian researcher Olena Predko (2019: 36-37) "Christianity offers consideration of faith in the existential and anthropological sense: as the basis for worldview and spiritual orientation, as an existence through which a man actualizes and realizes his life-creating potential ... In this context, its core content combines moral and ethical, intellectual (cognitive) and aesthetic principles. In general, moral and ethical principles, which serve as an indicator and determines the completeness of social and individual existence, is a priority in the structural hierarchy of religious faith.

The currently popular anthropological project of postmodernism inevitably merges with the imperative of Kant, and through it - with the gospel commandments. Although some representatives of this philosophy currently renounce the "metaphysical" justifications of human behavior, but, according to the authoritative French philosopher Emmanuel Levinas (1997), ethical commands come to us from a transcendental divine source. It is clear that these views show the connection between the postmodern anthropological concept and Christian philosophy. These philosophical trends do not oppose the mind and soul, but indicate their inseparable co- 
Nesprava Mykola, Rizak Mykhailo, Volkov Vladlen, Voluiko Oksana y Skrypa Yevhenii Christian interpretation of anthropological guidelines for lawmaking

existence, as a result of which legal consciousness is formed as an awareness of natural law:

\footnotetext{
Human mind opens the door to the soul. Our innate desire for truth may take the highest form in the moral quest when we seek for good and want to avoid evil, or at least when we understand that we must make moral choices. This moral meaning or ability is natural in order to be a human; therefore, it is defined as a natural law (Elliott, 2018: 128).
}

When formulating the anthropological foundations of the Christian concept of lawmaking, we proceed from these conclusions. According to this concept, theocentrism and anthropocentrism do not oppose each other, but combine in an integrated theological and anthropological image of a man. Using the theory of "synergistic anthropology" (philosophical direction, according to which the development of a new human discourse is based on these two trends), developed by Khoruzhyi (1998), we draw our conclusions based primarily on the Christology of Christian anthropology. Its cornerstone is the postulate of the union of a man and God in Christ, which is a prerequisite for a synergistic holistic interpretation of the image of a man as a whole, which combines "homo sapiens" and "homo spiritus". However, we deny the conservative thesis of theology about the hierarchical construction of a man, and, consequently, about the constant of the hierarchy of values in the process of human creation. We assume that a man is not just a predetermined linear entity: either a rational actor placed in the plane of social relations, or a spiritual ascetic who must renounce everything earthly. Man is a complex multilevel synergetic (chaotic, indefinite) set of spiritual energies and anthropological manifestations. Using the statement of John of Damascus (2009: 204), we can state that such a set is "the force of intelligent soul, which is natural and the first, the one that constantly moves". We pay particular attention to the definition of "intelligent soul", which reflects both unity and fluidity in the Christian interpretation of "homo spiritus" and "homo sapiens". Thus, a man is seen as constantly changing being, as a plurality in which material and spiritual motivations are combined through the prism of religious synergetic. It is important to pay attention, in this context, to the opinion of Abbot Benjamin (Novik) (1999), who argues that Christianity is turned to be identical to human nature in all its complexity, and therefore, in principle, everything must be rethought in the light of Christianity.

This understanding of the Christian interpretation of the image of a man and the teleology of human creativity makes it possible to present a synergetic approach to the interpretation of the values of lawmaking. The basis for this understanding is the statement of authoritative Ukrainian philosopher of law Bandura, who arguesthat, on the one hand, man is a spiritual being (2015), and on the other hand, man is a legal being (2016). It is important to emphasize that the zone of intersection of these two incarnations is a plane of morality. According to the anthropological 
foundations of the Christian concept of lawmaking, man as a subject of moral consciousness, must be guided by the dictates of moral law, which is the embodiment of divine providence. Thus, the law must, on the one hand, motivate a man as a legal being to act in a way that meets the aspiration to a higher moral imperative, and on the other hand, the ethical principles of Christianity, which are perceived by a man as a spiritual being, should be higher criteria of law.

This approach opposes classical positivism in lawmaking, which is based on secular rationalism and focuses not on spiritual values but on the recognition of the legal system, which consists of legal prescriptions, and thus focuses on the structure of law as a set of regulations and court precedents. Positivism used only the institutional platform to characterize "homojuridicus" (legal being), which was naturally accompanied by the basic provisions of classical rationality. A person: "Has always been perceived as a formalized structure that acted as a legal structure with certain legal qualities and properties" in such a legal reality (Novik 1999: 330). Besides, in the matrix of positivism, which essentially imitates Hobbes, an individual realizes the need for law and order, i.e. common norms for all people, only under the threat of violence, and this threat justifies the mechanical force of artificial personality - the State. Obviously, any truly democratic legal order is out of question in this case.

Therefore, the emphasis in substantiating the goals of lawmaking is on its anthropological and axiological essence from the standpoint of postclassical philosophy of law. The content of lawmaking in the postclassical interpretation is not in the production of instruments of formal external coercion, but in the socio-constructivist development of incentives to regulate life, taking into account the inner world and human freedom, which actually determine the true goals of human creativity. Religious thinkers (we consider primarily Christian doctrine) also believe that law only manifests itself in the external, spatial and corporeal world; but unlike postmodernists, they emphasize that the scope of its implementation and operation remains human soul, in which law acts with the force of objective value. Revealing the Christian interpretation of the teleology of law, the Russian philosopher Ilyin (1993: 45) emphasized that:

\footnotetext{
Spiritual purpose of law is to live in the souls of people, filling them with its content and thus forming internal impulses in their minds that affect their lives and their external way of action. The task of law is to create motives in the human soul for better behavior.
}

Human life is impossible outside the legal form, but a man must perceive this legal form independently, perceive the limits of his (her) will and maintain them as necessary and sacred, God-established limit of his (her) behavior. This self-commitment, from the point of view of the Christian interpretation of human creativity, remains the main way of life 
for "homo juridicus". The practical significance of this formula is that under such conditions the respect for law will not be imposed by the State, but based on a deep personal belief in its effectiveness as a means of regulating public relations. At the same time, Christian philosophy interprets legal consciousness as a reflection of the precepts of the "highest law", because it considers law to be derived from the Divine law, as conditioned by the gospel commandments. Thus, analyzing the law-making process, the founder of Ukrainian cardiocentrism Yurkevich (1990: 346) came to the following conclusion: "The primary principles of human legal activity are the Christian moral laws as general ideas of goodness and love. Moral laws are generated by the human heart, and the mind fixes them in the form of law".

Obviously, lawmaking as a form of stimuli for the behavior of social actors, according to Christian philosophers, should be focused on the meanings and ideals that produce legal consciousness on the basis of moral values of love, mercy and charity generated by spirituality as a mutual ascent of God to man and man to God, which is the purpose of human creativity in its Christian interpretation.

\section{Conclusion}

According to Christian interpretation, the human creation of a legal being occurs through the implementation of evangelical values in the legal consciousness, to which a man ascends in the process of his spiritual development, and which a man comprehends in accordance with a particular life situation with his own mind and according to which he acts in the legal field on his own free will. At the same time, while emphasizing the service of the public good as the goal of human creativity, Christianity views lawmaking as a reasonable production of incentives and the imposition of sanctions on social actors as the objects of law. In turn, lawmaking by a person as a subject of law is based on moral values as a reflection of the higher law through faith, which is manifested by human spirit, and corresponds to the interests articulated by social actors in a rational form. Similarly, these processes occur not only at the individual level but also at the group level, including the social level as a whole. In this case, they are not dialectical but synergistic.

That is, they do not replace each other in a clear sequence, but are in a state of fluidity and turbulence, interpenetration and co-existence. This synergy of mental, spiritual and legal principles and aspirations, in our opinion, appears to be the attributive essence of a man, which is revealed by modern Christian anthropology in the context of its application by the philosophy of law. Moreover, some authors are inclined to believe that a 
man is the core of the ontological sense of society, religion, State and law. It is the reliability of the interpretation of human identity, above all its axiological component, that directly determines the functioning of society and the State (Palahuta et al, 2020).

\section{Bibliographic References}

BANDURA, Oleh. 2015. "Axiology of law as a component of the philosophy of law” In: Philosophical and methodological problems of law. No 1-2, pp. $45-56$.

BANDURA, Oleh. 2016. "Ontology of law as a component of the philosophy of law (some considerations)" In: Philosophical and methodological problems of law. No. 2, pp. 55- 66 .

CC BY EUROPEAN VALUES. 2016. Definition of the most basic European Values and their significance for our modern society. Available online. In: http://europaeischewerte.info/fileadmin/templates/Documents/ ewdef_en.pdf. Date of consultation: 27/08/2020.

DAMASKIN, Ioann. 2009. An Accurate Statement of the Orthodox Faith. Osnovy. Moscow, Russia.

ELLIOTT, Peter. 2018. "The Human Person: An Introduction to Christian Anthropology" In: To Know, Worship \& Love (KWL). Available online. In: https://www.kwl.com.au/blog/liturgy/the-human-personan-introduction-to-christian-anthropology/. Date of consultation: 27/08/2020.

FOUCAULT, Paul-Michel Foucault. 2003. L'archeologie du Savoir (translated from the French by Victor Shovkun). Osnovy. Kyiv, Ukraine.

ILYIN, Ivan. 1993. On the essence of legal consciousness. Rarog. Moscow, Russia.

KANT, Immanuel. 1995. Critique of pure reason. Nauka. Saint-Petersburg, Russia.

KHORUZHYI, Serhei. 1998. To the phenomenology of ascetic. Osnovy. Moscow, Russia.

LEVINAS, Emmanuel. 1997. Philosophy, Justice and Love (translated from the French by Oleksandr Dymko). Dukh i Litera. Kyiv, Ukraine. 
MAKSYMOV, Serhii. 2009. Legal anthropology: the humanistic nature of law. Pravo. Kharkiv, Ukraine.

MARCHENKO, Oleksii. 2005. Searching for God as Man-Making: Philosophical and Personalistic Analysis of the Evolution of Religious and Ethical Thought in Ukraine. PhD Dissertation. Taras Shevchenko National University of Kyiv.

MYKULANYNETS, Lesia. 2019. "Image of Human in the Postmodern Epoch" In: Anthropological Measurements of Philosophical Research. Available online. In: doi: 10.15802/ampr.voi16.141904. Date of consultation: 27/08/2019.

NIETZSCHE, Friedrich. 2015. The Gay Science (translated from the German by Victor Toporov). Azbuka. Moscow, Russia.

NOVIK, Veniamin. 1999. Orthodoxy. Christianity. Democracy. Available online. In: http://www.gumer.info/bogoslov_Buks/ortodox/novik/ index.php. Date of consultation: 29/08/2020.

OGNEVIUK, Hanna. 2018. "Anthropological Approaches in Legal Certainty" In: Anthropological Measurements of Philosophical Research. Available online. In: doi: 10.15812/ampr.v014.150750. Date of consultation: 27/08/2019.

PALAHUTA, Vadym, ZHAROVSKA, Iryna, KOVALCHUK, Vitaliy; SKLIAR, Anna. 2020. "Anthropological justification of the modern change of axiological determinants under the influence of religious factors" In: Amazonia Investiga. Vol. 9, No.31, pp. 64 -70.

PAVLOV, Valierii. 2016. Anthropological concept of law. Postclassical ontology of law. Aleteiia. Saint-Petersburg, Russia.

PREDKO, Olena. 2019. "Religious Faith: Existential-Antropological Meanings" In: Anthropological Measurements of Philosophical Research. Available online. In: doi: 10.15802/ampr.voi16.186936. Date of consultation: 15/08/2019.

YURKEVYCH, Pamfil. 1990. Peace with a neighbor as the condition for Christian community (Proceedings of the Kiev Theological Academy, 1860). Pravda. Moscow, Russia. 


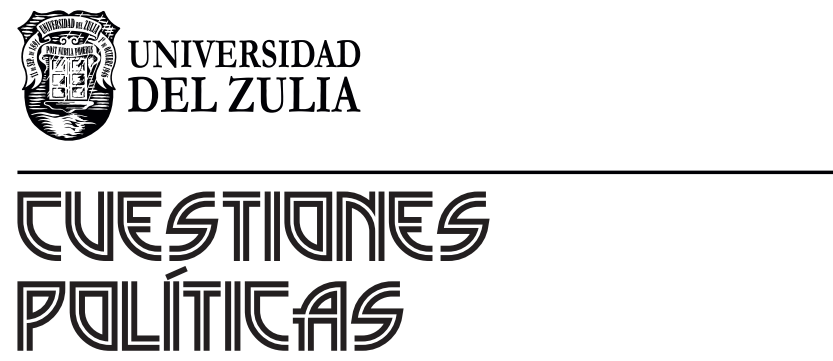

Vol.38 NEspecial

Esta revista fue editada en formato digital y publicada en octubre de 2020, por el Fondo Editorial Serbiluz, Universidad del Zulia. Maracaibo-Venezuela 